\title{
Minat Beli: Peran Citra Merek yang Dipersepsikan oleh Konsumen Produk Otomotif
}

\author{
U. Ramadhani ${ }^{1}$, L. A. Wibowo, \& B. Widjajanta \\ Universitas Pendidikan Indonesia \\ ulfharamadhani12@gmail.com
}

\begin{abstract}
This study aims to reveal the brand image and purchase interest in Daihatsu Terios in Indonesia. This study used a descriptive approach with explanatory survey method. The unit of analysis in this study is prospective consumers Daihatsu Terios in Indonesia as many as 120 orang.Teknik collecting data field study questionnaires. The data analysis technique used is descriptive technique using frequency distribution. Research findings showed that the image of the brand image are in the good category and description buying interest in the excellent category. Differences in this study lies in the object of research, study time, measuring tools, literature used, the theory used and the results of researchswitching barriers and customer loyalty.
\end{abstract}

\footnotetext{
ABSTRAK

Penelitian ini bertujuan untuk mengetahui gambaran citra merek dan minat beli pada Daihatsu Terios di Indonesia. Penelitian ini menggunakan pendekatan deskriptif dengan metode explanatory survey. Unit analisis pada penelitian ini yaitu calon konsumen Daihatsu Terios di Indonesia sebanyak 120 orang. Teknik pengumpulan data yaitu studi lapangan dengan penyebaran kuesioner. Teknik analisis data yang digunakan adalah teknik deskriptif dengan menggunakan distribusi frekuensi. Hasil temuan penelitian menunjukkan bahwa gambaran citra merek berada pada kategori baik dan gambaran minat beli pada kategori sangat baik. Perbedaan dalam penelitian ini terletak pada objek penelitian, waktu penelitian, alat ukur, literatur yang digunakan, teori yang digunakan dan hasil penelitian hambatan berpindah dan loyalitas pelanggan
}

\section{PENDAHULUAN}

Pemasaran bertujuan untuk mempengaruhi bagaimana pelanggan berpikir dan bertindak (Philip Kotler \& Armstrong, 2016). Saat ini ada banyak organisasi yang bekerja di pasar untuk memberikan produk sesuai dengan kebutuhan konsumen dan untuk bersaing satu sama lain (Farooq, Habib, \& Aslam, 2015). Memiliki wawasan faktor-faktor memungkinkan pemasar untuk lebih mengetahui dan memprediksi tidak

\author{
ARTICLE INFO: \\ Article history: \\ Received 120 February 2019 \\ Revised 20 February 2019 \\ Accepted 22 February 2019 \\ Available online 24 May \\ 2019
}

Keywords:

Brand Image; Purchase

Intention; Prospective

Consumers,

\section{Kata Kunci:}

Citra Merek; Minat Beli;

Calon Konsumen 
diubah oleh pengaruh harga, persepsi kualitas dan nilai persepsi (Zeithaml, 1988). Selain itu, konsumen akan terpengaruh oleh dorongan internal dan lingkungan eksternal selama proses pembelian (Grewal, Krishnan, Baker, \& Borin, 1998). Perilaku mereka akan didorong oleh motivasi fisiologis yang merangsang respon mereka, membawa mereka ke toko ritel untuk memenuhi kebutuhan mereka (Kim \& Jin, 2001).

Paradigma minat beli dapat membantu produsen yang membutuhkan data untuk menyelidiki apa faktor yang membuat minat beli terjadi di pasar dan di antara konsumen, minat beli dapat menjadi alat bagi produsen untuk mendapatkan informasi bagaimana produk yang mereka hasilkan dapat membawa kepuasan kepada konsumen (Fandos \& Flavián, 2008). Penelitian tentang minat beli sudah banyak diteliti diberbagai industri, dengan menggunakan konsumen sebagai responden dari penelitian tersebut (Shah et al., 2012).

Penelitian sebelumnya menemukan temuan yang menarik mengenai minat beli yang memiliki dampak langsung terhadap perilaku pembelian konsumen seperti penelitian yang dilakukan pada luxury brand (Bian \& Forsythe, 2012). Penelitian lain dilakukan pada sebuah private label food product yang menunjukkan hubungan antara variabel hampir semua independen dan minat beli terhadap produk merek makanan private label (Jaafar, Lalp, \& Mohamed Naba, 2013). Hal serupa didapatkan dalam penelitian pada toko ritel di Pakistan yang menunjukkan efek positif citra merek dan kualitas pelayanan terhadap minat membeli konsumen (Arslan \& Zaman, 2014).

Penelitian terbaru menemukan bahwa minat beli mobil di Pakistan memiliki hubungan yang signifikan positif pada tiga variabel yaitu harga, produk, dan merek produk kualitas (Amir \& Asad, 2018). Adapun penelitian lain yang dilakukan pada industri otomotif mobil di Iran, hasil penelitian tersbut menyatakan bahwa citra merek berpengaruh positif pada minat beli konsumen (Jalilvand \& Samiei, 2012). Penelitian yang dilakakukan di Indonesia menyatakan bahwa citra merek berpengaruh terhadap minat beli dalam kasus minat beli konsumen pada produk mobil (Antoni \& Herianto, 2017).

Persaingan Industri otomotif Indonesia telah menjadi sebuah pilar penting dalam sektor manufaktur negara ini karena banyak perusahaan mobil yang terkenal di dunia membuka (kembali) pabrik-pabrik manufaktur mobil atau meningkatkan kapasitas produksinya di Indonesia, negara dengan ekonomi terbesar di Asia Tenggara. Indonesia mengalami transisi yang luar biasa karena berubah dari hanya menjadi tempat produksi mobil untuk diekspor (terutama untuk wilayah Asia Tenggara) menjadi pasar penjualan (domestik) mobil yang besar karena meningkatnya produk domestik bruto (PDB) per kapita.

Berdasarkan Tabel 1.1 Data Wholesales by Brand, penjualan 2014-2017 tertinggi masih di tempati oleh merek Toyota. Dari 38 merek yang menjadi anggota Gaikindo, 15 di antaranya berasal dari Jepang. Kelompok Jepang memang jumlahnya terbesar di antara merek lain asal Korea Selatan, Amerika Serikat, Jerman, Inggris, India, dan China. Pada 2017, Indonesia menjual 1.079.534 unit mobil sedangkan total seluruh merek Jepang membukukan penjualan 1.060.236 unit. Lebih tepatnya, merek Jepang menguasai 98,21 persen pasar mobil di Indonesia pada 2017. Kontributor terbesar merek Jepang tentu saja sudah kita kenal semua, yaitu Toyota (34 persen), Honda (17 persen), Daihatsu (17 persen), Suzuki (10 persen), dan Mitsubishi (7 persen), sedangkan penjualan Nissan masih berada pada posisi dibawah. Berikut Tabel 1.1 Data Wholesales by Brand tahun 20142017 di Indonesia :

\section{TABEL 1.1}

DATA WHOLESALES BY BRAND

\begin{tabular}{ccccc}
\hline \multirow{2}{*}{ MEREK } & \multicolumn{4}{c}{ DATA PENJUALAN } \\
\cline { 2 - 5 } & $\mathbf{2 0 1 4}$ & $\mathbf{2 0 1 5}$ & $\mathbf{2 0 1 6}$ & $\mathbf{2 0 1 7}$ \\
\hline Toyota & 399,119 & 321,818 & 381,570 & 371,332 \\
Honda & 159,147 & 159,253 & 199,364 & 186,859 \\
Daihatsu & 185,226 & 167,808 & 189,683 & 186,381 \\
Suzuki & 154,923 & 121,805 & 92,950 & 111,660 \\
Nissan & 28,493 & 25,108 & 13,153 & 14,488 \\
\hline
\end{tabular}

Sumber : www.gakindo.or.id 2017

Perkembangan teknologi yang kian memesat menjadikan berbagai produsen mobil terus menerus berlomba-lomba dalam menciptakan sebuah inovasi terbaru yang tentunya untuk 
memenuhi kebutuhan konsumennya. Mobil terdiri dari berbagai macam jenis, ada istilah - istilah baru untuk menamai tipe, atau jenis mobil tersebut, di antaranya adalah Sport Utility Vehicle (SUV), Multi Urpose Vehicle, hatchback, serta city car (www.viva.co.id).

Berdasarkan Gambar 1.1 Wholesales LSUV Januari - Juni 2017, pasar mobil Low Sport Utility Vehicle (LSUV) tidak terlalu diminati kelas menengah. Melihat dari data Gabungan Industri Kendaraan Bermotor Indonesia (Gaikindo), sepanjang semester awal 2017, LSUV terjual 53.592 unit secara wholesales nasional. Jumlah tersebut didapat dari delapan LSUV yang berasal dari tujuh merek berbeda. Mulai dari Honda HR-V 1.5L, Honda BR-V, Toyota Rush, Daihatsu Terios, Suzuki S-Cross, Chevrolet Trax, Mazda CX-3, dan Nissan Juke. Dari sisi peringkat, Honda mendominasi pasar melalui HR-V 1.5L. Sepanjang Januari hingga Juni 2017 penjualannya mencapai 19.094 unit, sementara urutan kedua ditempati saudaranya, BR-V, yakni 11.977 unit. Toyota Rush duduk di posisi ketiga dengan penjualan 11.533 unit sepanjang semestar awal. Sedangkan urutan keempat ditempati kembarannya, Daihatsu Terios, dengan angka 7.640 unit. Suzuki X4 menjadi juru kunci posisi lima besar dengan penjualan sepanjang semester awal 2017 sebanyak 1.938 unit. Sementara Chevrolet Trax menyusul pada peringkat keenam dengan 913 unit.Dua posisi terbawah ditempati Mazda CX-3 dan Nissan Juke. CX-3 yang baru saja diluncurkan pada Maret 2017 lalu hanya mampu mencatat penjualan 390 unit. Sedangkan Nissan Juke mulai kehilangan pamornya dengan penjualan 107 unit. Berikut Gambar 1.1 Wholesales LSUV Januari - Juni 2017

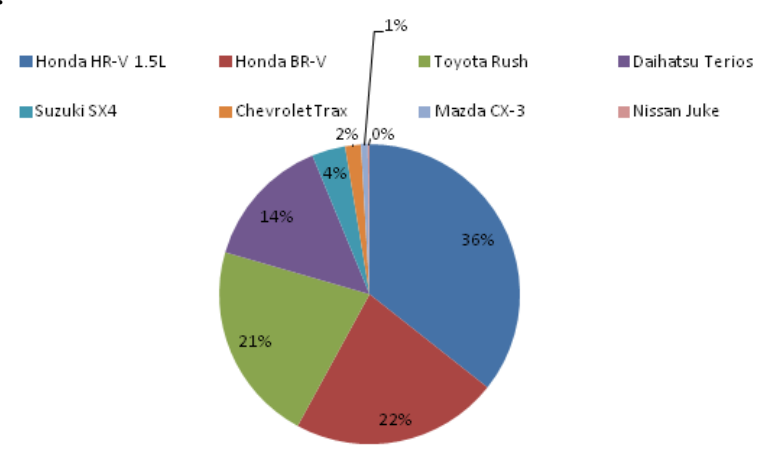

Sumber: otomotif.kompas.com

\section{GAMBAR 1.1 WHOLESALES LSUV JANUARI-JUNI 2017}

Berdasarkan Tabel 1.2 Top Brand Index Kategori Mobil LSUV, Toyota Rush mengalami peningkatan dari tahun 2016 ke 2017 sebesar 0,3\%, Honda CRV mengalami penurunan $0,9 \%$, diurutan ke tiga Toyota fortuner juga mengalami penurunan 4,8, berbeda dengan Mitsibushi Pajero Sport yang berada diurutan ke empat mengalami peningkatan sebesar 1,3, dan di urutan ke lima Daihatsu Terios mengalami peningkatan sebesar 1,5. Posisi dan penigkatan tersebut menunjukkan bahwa konsumen memiliki kesadaran merek terhadap Daihatsu Terios. Tinggi kesadaran konsumen akan merek, dan sebagai kemampuan konsumen dalam mengenali dan mengingat sebuah merek dalam situasi yang berbeda, membuat Daihatsu Terios bersaing dengan para pesaingnya. Berikut data Tabel 1.2 Top Brand Index Mobil LSUV di Indonesia tahun 2014-2017 :

TABEL 1.2

TOP BRAND INDEX KATEGORI MOBIL LSUV

\begin{tabular}{ccc}
\hline \multirow{2}{*}{ MEREK } & \multicolumn{2}{c}{ TBI } \\
\cline { 2 - 3 } & $\mathbf{2 0 1 6}$ & $\mathbf{2 0 1 7}$ \\
\hline Toyota Rush & $13.8 \%$ & $14.1 \%$ \\
Honda CRV & $15.5 \%$ & $14.6 \%$ \\
Toyota Fortuner & $18.8 \%$ & $14.0 \%$ \\
Mitsubishi Pajero Sport & $13.1 \%$ & $14.4 \%$ \\
Daihatsu Terios & $13.7 \%$ & $15.2 \%$ \\
\hline
\end{tabular}

Sumber : www.topbrand-award.com, 2017

Penjualan mobil Daihatsu selama 2017 mengalami penurunan di tengah pasar domestik yang mengalami pertumbuhan tipis. Berdasarkan data Gabungan Industri Kendaraan Bermotor Indonesia (Gaikindo), penjualan Daihatsu sepanjang tahun lalu tercatat 186.381 unit atau turun 1,7 persen dibandingkan dengan capaian pada tahun sebelumnya 189.683 unit. Penurunan angka penjualan ini disebabkan oleh kinerja yang melambat beberapa model, seperti KBH2T Alya, mobil sportif Terios, kendaraan kecil serbaguna Xenia, pikap Gran Max 1.3, dan pikap Hi Mak 1.0.

Penurunan penjualan juga dialami oleh Daihatsu Terios sepanjang 11 bulan pertama tahun 2017, Terios hanya meraup penjualan 
10.344 unit, atau 29,89 persen dari capaian pada periode yang sama tahun lalu 13.463 unit. Berikut data penjualan LSUV Januari-November 20162017 :

TABEL 1.3

PENJUALAN LSUV JANUARI-NOVEMBER 2016 - 2017

\begin{tabular}{ccccc}
\hline \multirow{2}{*}{ Model } & \multicolumn{2}{c}{$\mathbf{2 0 1 6}$} & \multicolumn{2}{c}{$\mathbf{2 0 1 7}$} \\
\cline { 2 - 5 } & Unit & Pangsa & Unit & Pangsa \\
\hline Honda HR-V 1.5 & 33,211 & $31 \%$ & 31,092 & $36 \%$ \\
Honda BR-V & 35,810 & $33 \%$ & 19,011 & $22 \%$ \\
Toyota Rush & 22,832 & $21 \%$ & 19,052 & $22 \%$ \\
Daihatsu Terios & 13,436 & $12 \%$ & 10,344 & $12 \%$ \\
Suzuki SX4 & 1,533 & $1 \%$ & 3,119 & $4 \%$ \\
Cheverlot Trax & 1,328 & $1 \%$ & 1,713 & $2 \%$ \\
Nissan Juke & 297 & $0 \%$ & 797 & $1 \%$ \\
Lainnya Captur, & 98 & $0 \%$ & 203 & $0 \%$ \\
Ecosport & 0 & $0 \%$ & - & $0 \%$ \\
Mazda CX-3 & & & & \\
\hline
\end{tabular}

Sumber : http://otomotif.bisnis.com

Dampak dari rendahnya minat beli dapat berpengaruh terhadap perilaku pembelian konsumen (Hussain, Ali, Ibrahim, Noreen, \& Ahmad, 2015), oleh karena itu pemasar mencoba untuk memahami kebutuhan konsumen yang berbeda dan setelah itu memahami perilaku konsumen yang berbeda memerlukan studi mendalam dari lingkungan internal dan eksternal (Khan, 2006). Kotler (2013) mengemukakan bahwa beberapa hal yang menjadi faktor dapat mempengaruhi minat beli, attitude towards the brand interaction (sikap terhadap interaksi merek), brand juga mempengaruhi niat pembelian seperti brand awareness, brand association, perceived quality, citra merek, dan brand loyalty (Shah et al., 2012).

Citra merek merupakan faktor yang digunakan untuk mengatasi permasalahan minat beli, karena jika suatu produk memiliki suatu image yang baik dimata masyarakat maka suatu produk tersebut menarik dan disenangi di masyarakat. Jika suatu produk itu mempunyai image yang baik otomatis brand tersebut dikenali oleh masyarakat hal itulah yang menimbulkan sebuah minat beli dimana masyarakat tertarik untuk membeli sebuah produk karena citra merek yang dimiliki oleh produk tersebut. Konsumen lebih cenderung membeli merek produk yang terkenal dengan citra merek positif sebagai cara untuk menurunkan risiko pembelian (Akaah \& Korgaonkar, 2005).

Rumusan masalah dalam penelitian ini adalah: (1) Bagaimana gambaran mengenai ciitra merek pada mobil Daihatsu Terios (2) Bagaimana gambaran mengenai minat beli konsumen pada mobil Daihatsu Terios (3) Bagiamana pengaruh dimensi citra merek yang terdiri dari attributes, benefits, dan overall evaluation terhadap minat beli konsumen pada mobil Daihatsu Terios baik secara simultan dan parsial.

Tujuan dilakukannya penelitian ini adalah untuk memberikan bukti empiris mengenai pengaruh Brand awareness terhadap minat belis yang dijabarkan sebagai berikut: (1) untuk memperoleh temuan mengenai gambaran citra merek mobil Daihatsu Terios (2) Untuk memperoleh temuan mengenai gambaran minat beli konsumen pada mobil Daihatsu Terios (3) Untuk memperoleh temuan mengenai pengaruh dimensi citra merek yang terdiri dari attributes, benefits, dan overall evaluation terhadap minat beli mobil Daihatsu Terios baik secara simultan dan parsial

\section{METODEPENELITIAN}

Penelitian ini dilakukan untuk mengalanisis minat beli terhadap peran citra merek yang dipersepsikan oleh konsumen produk otomotif di Indonesia. Variabel bebas (independent variable) atau variabel eksogen yang terdapat pada penelitian ini yaitu citra merek dengan attributes, benefits, dan overall evaluation. Sedangkan variabel terikat (dependent variable) atau variabel endogen pada penelitian ini yaitu minat beli dengan dimensi price, product, dan brand product quality.

Metode penelitian yang digunakan dalam penelitian ini adalah metode explanatory survei. Penelitian ini dilakukan dalam kurun waktu kurang dari satu tahun, maka metode yang digunakan yaitu cross sectional method. Metode penelitian cross sectional merupakan metode di mana data yang dikumpulkan hanya sekali dalam kurun waktu tertentu, mungkin selama beberapa hari, minggu atau bulan, untuk menjawab pertanyaan penelitian (Sekaran, 2003:135), sehingga penelitian ini 
seringkali disebut penelitian sekali bidik atau one snapshot (Hermawan, 2006:19). Teknik yang digunakan dalam menarik sampel pada penelitian ini adalah teknik simple random sampling, dengan jumlah sampel 120 responden. Teknik pengumpulan data yang digunakan adalah studi kepustakaan, studi lapangan dengan penyebaran kuesioner, dan studi literatur. Sedangkan teknik analisis data yang dilakukan adalah analisis deskriptif menggunakan distribusi frekuensi.

Analisis deskriptif digunakan untuk mencari kuatnya hubungan antara variabel melalui analisis korelasi dan membuat perbandingan rata-rata data sampel atau populasi tanpa perlu diuji signifikasinya. Alat penelitian yang digunakan dalam penelitian ini adalah angket atau kuesioner yang disusun berdasarkan variabel yang terdapat pada data penelitian, yaitu memberikan keterangan citra merek terhadap minat beli. Pengolahan data yang terkumpul dari hasil kuesioner dapat dikelompokkan kedalam tiga langkah, yaitu persiapan, tabulasi dan penerapan data pada pendekatan penelitian.

Untuk mengkategorikan hasil perhitungan, digunakan kriteria penafsiran persentase yang diambil dari $0 \%$ sampai $100 \%$. Penafsiran pengolahan data berdasarkan batas-batas disajikan pada Tabel 4 sebagai berikut.

Tabel 4 Kriteria Penafsiran Hasil Perhitungan Responden

\begin{tabular}{lll}
\hline No & \multicolumn{1}{c}{$\begin{array}{c}\text { Kriteria } \\
\text { Penafsiran }\end{array}$} & \multicolumn{1}{c}{ Keterangan } \\
\hline 1 & $0 \%$ & Tidak Seorangan \\
2 & $1 \%-25 \%$ & Sebagian Kecil \\
3 & $26 \%-49 \%$ & Hampir Setengahnya \\
4 & $50 \%$ & Setengahnya \\
5 & $51 \%-75 \%$ & Sebagian Besar \\
6 & $76 \%-99 \%$ & Hampir Seluruhnya \\
7 & $100 \%$ & Seluruhnya \\
\hline
\end{tabular}

Setelah mengkategorikan hasil perhitungan berdasarkan kriteria penafsiran, dibuat garis kontinum yang dibedakan menjadi lima tingkatan diantaranya sangat tinggi, tinggi, sedang, rendah dan sangat rendah. Garis kontinum ini dibuat untuk membandingkan setiap skor total tiap variabel untuk memperoleh gambaran variabel minat beli (Y) dan variabel citra merek (X).

\section{HASIL DAN PEMBAHASAN}

Gambaran Citra Merek

Variabel citra merek terdiri dari tiga dimensi dengan 14 indikator. Dimensi pertama yaitu attributes dengan indikator desain merek, kualitas merek, harga yang ditawarkan, fitur produk, dan fungsional. Dimensi kedua yaitu benefits dengan indikator pelayanan, citra produk, dan kesan. Dimensi yang ketiga yaitu overall evaluation dengan indikator peneliaian, kepercayaan, posisi merek dibenak konsumen, popularitas merek, dan reputasi merek.

Hasil pengolahan data mengenai kategori variabel citra merek terlihat pada Gambar 2 berikut ini:

\section{Gambar 2 Garis Kontinum Citra Merek}

$$
\begin{array}{|l|l|l|l|l|l|l|l|l|l|l|l|l|l}
\begin{array}{l}
\text { Sangat } \\
\text { Buruk }
\end{array} & \text { Buruk } & \begin{array}{l}
\text { Cukup } \\
\text { Buruk }
\end{array} & \text { Sedang } & \begin{array}{l}
\text { Cukup } \\
\text { Baik }
\end{array} & \begin{array}{l}
\downarrow \\
\text { Baik }
\end{array} & \begin{array}{l}
\text { Sangat } \\
\text { Baik }
\end{array} \\
1.680 & 3.120 & 4.560 & 6.000 & 7.440 & 8.880 & 10.320 & 11.760
\end{array}
$$

Sumber : Hasil Pengolahan Data, 2018

Berdasarkan hasil penelitian dari kuesioner yang disebar kepada 120 responden, dapat diketahui bahwa citra merek pada Daihatsu Teerios pada calon pembeli di Indonesia mendapatkan skor sebesar 9.661 dari skor ideal yaitu 11.760. Jika dilihat berdasarkan dimensi, pada Tabel 5 dimensi yang mendapat skor paling tinggi adalah dimensi attributes dengan perolehan skor sebesar 4,175 atau $82,84 \%$. Sementara dimensi yang mendapatkan skor paling rendah adalah dimensi benefits dengan perolehan skor sebesar 2.082 atau $82,62 \%$. Jika dilihat berdasarkan indikator, indikator yang mendapatkan skor paling tinggi adalah reputasi merek Daihatsu Terios dengan perolehan skor 709. Sedangkan indikator yang mendapatkan skor paling rendah adalah harga yang ditawarkan dibandimgkan dengan kualitas Daihastu Terios dengan perolehan skor 664. Berikut Tabel 5 Rekapitulasi tanggapan mengenai dimensi citra merek

Tabel 5

Rekapitulasi Tanggapan Mengenai Dimensi Citra Merek

\begin{tabular}{llcccc}
\hline No & Dimensi & Skor & $\begin{array}{c}\text { Rata- } \\
\text { Rata } \\
\text { Skor }\end{array}$ & Skor Ideal & $\%$ \\
\hline 1 & Attributes & 3,404 & $1,134.67$ & 4,200 & 81.05 \\
2 & Benefits & 2,082 & 694.00 & 2,520 & 82.62
\end{tabular}




\begin{tabular}{clcccc}
3 & $\begin{array}{l}\text { Overall } \\
\text { Evaluation }\end{array}$ & 4,175 & $1,391.67$ & 5,040 & 82.84 \\
\hline Total & $\mathbf{9 , 6 6 1}$ & $\mathbf{3 , 2 2 0 . 3 3}$ & $\mathbf{1 1 , 7 6 0}$ & $\mathbf{8 2 . 1 7}$
\end{tabular}

Sumber: Hasil pengolahan data, 2018

Citra merek yang lebih positif memang memiliki efek menurunkan risiko persepsi produk konsumen dan meningkatkan umpan balik positif dari konsumen (Monroe, 2017), oleh karena itu, konsumen umumnya percaya bahwa mereka dapat melakukan pembelian yang memuaskan dengan memilih merek-merek terkenal dan juga menurunkan risiko pembelian. Penelitian yang dilakukan mengenai dimensi citra merek oleh (Jalilvand \& Samiei, 2012) mengatakan bahwa attributes, benefits dan overall evaluation dapat diandalkan dan valid, serta skala tersebut dapat digunakan untuk studi mengenai tingkat agregat antara beberapa citra merek kategori produk yang berbeda, untuk studi berbagai persaingan dalam kategori produk tertentu, untuk studi pada tingkat merek individual, dan untuk studi lintas budaya. Skala baru ini menjanjikan sebuah instrumen

praktis untuk penelitian branding dan penting bagi akademisi dan praktisi.

\section{Gambaran Minat Beli}

Variabel minat beli terdiri dari tiga dimensi dengan 10 indikator. Dimensi pertama yaitu price dengan harga prom, angsuran, dan deposit. Dimensi kedua yaitu product dengan indikator kualitas mobil, teknologi mobil dan penampilan. Dimensi yang ketiga yaitu brand product quality dengan indikator Logo Daihatsu Terios yang membedakan dengan merek lain, keunggulan merek Daihatsu Terios, ergonomis, dan kepercayaan pada pilihan produk.

Hasil pengolahan data mengenai kategori variabel citra merek terlihat pada Gambar 3 berikut ini:

\section{Gambar 3 Garis Kontinum Minat Beli}

$$
\begin{array}{|l|l|l|l|l|l|l|l|}
\begin{array}{l}
\text { Sangat } \\
\text { Buruk }
\end{array} & \text { Buruk } & \begin{array}{l}
\text { Cukup } \\
\text { Buruk }
\end{array} & \text { Sedang } & \begin{array}{l}
\text { Cukup } \\
\text { Baik }
\end{array} & \begin{array}{l}
\text { Baik } \\
\downarrow
\end{array} & \begin{array}{l}
\text { Sangat } \\
\text { Baik }
\end{array} \\
\hline 1.200 & 2.229 & 3.258 & 4.287 & 5.316 & 6.345 & 7.374 & 8.400
\end{array}
$$

Sumber: Hasil pengolahan data, 2018

Berdasarkan hasil penelitian dari kuesioner yang disebar kepada 120 responden, dapat diketahui bahwa minat beli Daihatsu di Indonesia mendapatkan skor sebesar 6.851 dari skor ideal yaitu 8.400. Jika dilihat berdasarkan dimensi, pada Tabel 6 dimensi yang mendapat skor paling tinggi adalah dimensi brand product quality dengan perolehan skor sebesar 2.774 atau $82.56 \%$. Sementara dimensi yang mendapatkan skor paling rendah adalah dimensi price dengan perolehan skor sebesar 1.985 atau $78,77 \%$. Jika dilihat berdasarkan indikator, indikator yang mendapatkan skor paling tinggi adalah Daihatshu terios menawarkan tampilan sporty \& mewah sehingga mendorong minat beli dengan perolehan skor 700. Sedangkan indikator yang mendapatkan skor paling rendah adalah Angsuran yang ditawarkan Daihatsu Terios mendorong minat beli dengan perolehan skor 647. Berikut Tabel 6 Rekapitulasi tanggapan mengenai dimensi citra merek

\section{Tabel 6 \\ Rekapitulasi Tanggapan Mengenai Dimensi Minat Beli}

\begin{tabular}{clcccc}
\hline No & Dimensi & Skor & $\begin{array}{c}\text { Rata }- \\
\text { Rata Skor }\end{array}$ & $\begin{array}{c}\text { Skor } \\
\text { Ideal }\end{array}$ & \% \\
\hline 1 & Price & 1,985 & 661.6667 & 2,520 & 78.77 \\
2 & Product & 2,094 & 698 & 2,520 & 83.10 \\
& Brand & & & & \\
& Product & & & & \\
3 & Quality & 2,774 & 924.6667 & 3,360 & 82.56 \\
\hline & Total & $\mathbf{6 . 8 5 1}$ & $\mathbf{2 2 8 4 . 3 3 3}$ & $\mathbf{8 , 4 0 0}$ & $\mathbf{2 4 4 . 4 2}$ \\
\hline
\end{tabular}

Sumber: Hasil pengolahan data, 2018

Minat pembelian didefinisikan sebagai perencanaan seseorang melakukan pembelian barang atau jasa di masa depan (Hadi \& Manaf, 2015). Penelitian lain yang dilakukan mengenai minat beli dengan dimensi price, product, dan brand product quality oleh (Amir \& Asad, 2018). Temuan pada penelitian tersebut menggambarkan bahwa tiga variabel independen harga, produk, dan kualitas produk merek memiliki hubungan signifikan positif dengan minat pembelian konsumen terhadap mobil. Para manajer di industri otomotif serta pembuat kebijakan akan menganggap studi tersebut bermanfaat, ketika mereka akan membuat strategi, misalnya pemasaran dan mengembangkan kebijakan

\section{KESIMPULAN DAN SARAN}

Berdasarkan hasil penelitian dipembahasan dikemukakan kesimpulan sebagai berikut: 
Gambaran mengenai citra merek yang dapat dilihat dari dimensi - dimensinya attributes, benefits, dan overall evaluation berada pada kategori yang baik. Hal ini menunjukan bahwa citra merek yang diberikan Daihatsu Terios di Indonesia dapat dikatakan baik. Dimensi benefits merupakan indikator yang memiliki persentase penilaian paling rendah, dan attributes merupakan indikator yang memiliki persentase penilaian paling tinggi.

Gambaran mengenai minat beli yang dapat dilihat dari dimensi-dimensinya price, product, dan brand product quality berada pada kategori baik. Hal ini menunjukan bahwa minat beli yang dimiliki Daihastu Terios di Indonesia dapat dikatakan baik. Dimensi price memiliki persentase penilaian yang paling rendah, sedangkan brand product quality merupakan indikator yang memiliki persentase penilaian paling tinggi.

Pengaruh langsung maupun tidak langsung antara dimensi-dimensi citra merek terhadap minat beli pada Daihatsu Terios di Indonesia yang paling besar pengaruhnya secara parsial yaitu pengaruh social attributes terhadap minat beli dan pengaruh paling kecil yaitu pengaruh antara benefits (X2) terhadap minat beli(Y). Dimensi dari citra merek yang menguatkan dimensi lainnya terhadap variabel eksogen yaitu attributes (X1), sedangkan dimensi yang melemahkan dimensi lainnya terhadap variabel eksogen yaitu benefits (X2).

Berdasarkan hasil penelitian, beberapa saran mengenai pengaruh dimensi citra merek terhadap minat beli Daihatsu Terios, yaitu: 1) Dimensi citra merek Daihastu Terios secara menyeluruh memiliki pengaruh yang kategorikan baik, tetapi ada beberapa yang perlu dilakukan perbaikan yaitu pada dimensi benefits yang memiliki nilai paling rendah, sehingga perusahaan perlu untuk mengambil sikap yang lebih agresif dengan meningkatkan pelayanan, citra produk dan kesan yang baik. Hal ini perlu diperhatikan oleh perusahaan agar dapat meningkatkan minat belinya. 2) Minat beli Daihastu Terios yang terdiri dari dimensi price, product dan, brand product quality termasuk dalam kategori baik. Dari ketiga dimensi tersebut price (harga) memiliki kontribusi nilai yang paling rendah. Untuk meningkatkan nilai minat beli, maka perusahaan perlu memperbaiki kebijakan dalam angsuran yang ditawarkan, ini di karena angsuran yang ditawarkan mempunyai kontribusi paling rendah dalam mendorong minat beli, dan 3) Hasil penelitian ini menyatakan bahwa dimensi benefitss memiliki nilai yang paling rendah terhadap minat beli. Maka penulis merekomendasikan agar perusahaan dapat melakukan perbaikain pada peningkatan pelayanan, citra produk, dan kesan yang baik, sehingga dapat meningkatakan minat beli.

\section{DAFTAR PUSTAKA}

Ananda Sabil Hussein, P. . (2016). the Effect of Trust and Brand Engagement on Mobile Telecommunication Customer Loyalty: the Mediating Effect of Brand Engagement, (September), 20-22. https://doi.org/10.13140/RG.2.2.10734.8 $\underline{2245}$

Akaah, \& Korgaonkar. (2005). A Conjoint Investigation of the Relative Importance of Risk Relievers in Direct Marketing, (56), 297-312.

Amir, A., \& Asad, M. (2018). Consumer ' s Purchase Intentions towards Automobiles in Pakistan, 202-213. https://doi.org/10.4236/ojbm.2018.61014

Antoni, \& Herianto, M. (2017). Pengaruh Brand Image Dan Kepercayaan Merek Terhadap Minat Beli Konsumen Pada Produk Mobil Toyota Etios Valco (Studi Pada PT. Agung Automall Pekanbaru), 4(1), 1-10.

Arslan, M., \& Zaman, R. (2014). Impact of Brand Image and Service Quality on Consumer Purchase Intention: A Study of Retail Store in Pakistan, 4(22), 98-106.

Bian, Q., \& Forsythe, S. (2012). Purchase intention for luxury brands: A cross cultural comparison 弥. Journal of Business Research, 
65(10),

$1443-1451$.

https://doi.org/10.1016/j.jbusres.2011.10.010

Durmaz, Y. (2014). The impact of psychological factors on consumer buying behavior and an empirical application in Turkey. Asian Social Science, 10(6), 194-204. https://doi.org/10.5539/ass.v10n6p194

Fandos, C., \& Flavián, C. (2008). Intrinsic and extrinsic quality attributes, loyalty and buying intention: an analysis for a PDO product.

https://doi.org/10.1108/00070700610682337

Farooq, S., Habib, S., \& Aslam, S. (2015). Influence of Product Packaging on Consumer Purchase Intentions. International Journal of Economics, Commerce and Management, III(12), 538-547.

Grewal, D., Krishnan, R., Baker, J., \& Borin, N. (1998). The effect of store name, brand name and price discounts on consumers' evaluations and purchase intentions. Journal of Retailing, 74(3), 331-352. https://doi.org/10.1016/S00224359(99)80099-2

Hadi, A., \& Manaf, A. (2015). The Mediating Effect of Consumers 'Purchase Intention: A Perspective of Online Shopping Behavior among Generation Y, 18, 101-112.

Hussain, S., Ali, S., Ibrahim, M., Noreen, A., \& Ahmad, S. F. (2015). Impact of product packaging on consumer perception and purchase intention. Journal of Marketing and Consumer Research, 10(2011), 1-10.

Jaafar, S. N., Lalp, P. E., \& Mohamed Naba, M. (2013). Consumers' Perceptions, Attitudes and Purchase Intention towards Private Label Food Products in Malaysia. Asian Journal of Business and Management Sciences, 2(8), 73-90.

Jalilvand, M. R., \& Samiei, N. (2012). The effect of electronic word of mouth on brand image and purchase intention An empirical study in the automobile, 30. https://doi.org/10.1108/02634501211231946

Khan, M. (2006). Consumer Behaviour and Advertisement Management. New Delhi: NEW AGE INTERBATIONAL PUBLISHERS.

Khaniwale, M. (2015). Consumer Buying Behavior. International Journal of Innovation and Scientific Research, 14(2), 278-286. Retrieved from http://www.ijisr.issrjournals.org/abstract.php?article=IJISR-14129-01

Kim, J. O., \& Jin, B. (2001). Korean consumers' patronage of discount stores: domestic vs multinational discount store shoppers' profiles. Journal of Consumer Marketing, 18(3), 236-255. https://doi.org/10.1108/07363760110393092

Kotler, P., \& Armstrong, G. (2013). Principles of Marketing. World Wide Web Internet And Web Information Systems (Vol. 42). https://doi.org/10.2307/1250103

Kotler, P., \& Armstrong, G. (2016). Principles of Marketing. https://doi.org/10.2307/1250103

Kotler, P., Keller, K., Brady, M., Goodman, M., \& Hansen, T. (2016). Marketing management. https://doi.org/10.1080/08911760903022556

McCarthy, B. (2016). Consumer Behaviour and $P R$. Retrieved from http://bookboon.com/en/consumerbehaviour-pr-ebook.pdf

Monroe, K. B. (2017). The Moderating Effect of Prior Knowledge on Cue Utilization in Product Evaluations, (January). https://doi.org/10.1086/209162

Richardson, P. S., \& Dick, A. S. (2015). Extrinsic and Intrinsic of Store Perceptions Cue Effects on Brand, 58(4), 28-36. 
Shah, S. S. H., Aziz, J., Jaffari, A. R., Waris, S., Ejaz, W., Fatima, M., \& Sherazi, S. K. (2012). The Impact of Brands on Consumer Purchase Intentions. Asian Journal of Business Management, 4(2), 105-110. Retrieved from http://maxwellsci.com/print/ajbm/v4-105110.pdf

Shih, S. P., Yu, S., \& Tseng, H. C. (2015). The Study Of Consumers' Buying Behavior And Consumer Satisfaction In Beverages Industry In Tainan, Taiwan. Journal of Economics, Business and Management, 3(3), 391-394. https://doi.org/10.7763/JOEBM.2015.V3.21 5

Tee, P. K., Gharleghi, B., Chan, B., Samadi, B., \& Balahmar, A. A. (2015). Purchase Intention of International Branded Clothes Fashion among Younger's in Jakarta. International Journal of Business and Social Research, 5(8), 08-17.

Zeithaml, V. A. (1988). Consumer Perceptions of Price, Quality, and Value: A Means-End Model and Synthesis of Evidence. Journal of Marketing, 52(3), 2-22. https://doi.org/10.2307/1251446 